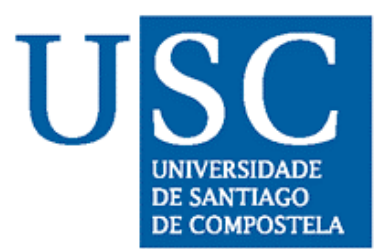

\title{
Synthesis of Tetrahydroxyazepanes from Shikimic Acid
}

\author{
Marcos A. González, Darren Poole, Juan C. Estévez* and Ramón J. Estévez* \\ Departamento de Química Orgánica. Universidade de Santiago de Compostela. \\ 15782 Santiago de Compostela, ESPAÑA \\ e-mail: ramon.estevez@,usc.es
}

\begin{abstract}
.
We describe herein a novel synthetical application of shikimic acid, which consist of its transformation into $(3 R, 4 S, 5 R, 7 S)$-7-(hydroxymethyl)azepane-3,4,5-triol.
\end{abstract}

\section{INTRODUCTION.}

With the breakthroughs in Glycobiology, glycosidases have received considerable attention due to their use as biochemical tools and involvement in several important biological processes, such as digestion, the biosynthesis of glycoproteins and the catabolism of glycoconjugates. ${ }^{1}$ Accordingly, glycosidase inhibitors have been extensively investigated over the last two decades on account of their potential as therapeutic agents. ${ }^{1}$ Indeed, some examples have already been tested or approved for use in the treatment of various diseases such as Gaucher's disease, diabetes, cancer and viral infections - including AIDS. This situation has led to considerable effort in recent years aimed at understanding the structural types, mechanisms of action and synthesis of glycosidase inhibitors.

The most prominent glycosidase inhibitors are imino sugars, ${ }^{2}$ which are polyhydroxylated nitrogen-containing ring skeleton analogues of furanoses or pyranoses in which the ring oxygen is replaced by nitrogen. ${ }^{8}$ A great deal of synthetic effort has been focused on the preparation of substituted pyrrolidine or piperidine mimics of the corresponding sugars, including nojirimycin (1a) and deoxynojirimycin (1) $)$, the former being an imino sugar that can be regarded as the result of replacing the ring oxygen of D-glucose by a nitrogen. ${ }^{3}$ More recently, some higher homologues like azepanes (2) have been found to inhibit glycosidases, prompting efforts directed towards their synthesis and the study of their biological activity. ${ }^{4}$ Regarding to the molecular basis of 
this strong inhibitory activity, it was postulated that azepanes could probably adapt better to the active site of glycosidases due to them being structurally more flexible than the corresponding pyrrolidines and piperidines. ${ }^{5}$<smiles>[X]C1N[C@H](CO)[C@@H](O)[C@H](O)[C@H]1O</smiles>

$1 \mathbf{a}: \mathrm{X}=\mathrm{OH}, \mathbf{b}: \mathrm{X}=\mathrm{H}$

Figure 1<smiles>[R6]C1([R6])CN[C@H](CO)[C@@H](O)[C@H]1O</smiles>

2a: $\mathrm{R}_{1}=\mathrm{R}_{3}=\mathrm{H} ; \mathrm{R}_{2}=\mathrm{R}_{4}=\mathrm{OH}$ 2b: $\mathrm{R}_{2}=\mathrm{R}_{4}=\mathrm{H} ; \mathrm{R}_{1}=\mathrm{R}_{3}=\mathrm{OH}$

2c: $\mathrm{R}_{2}=\mathrm{R}_{3}=\mathrm{H} ; \mathrm{R}_{1}=\mathrm{OH} ; \mathrm{R}_{4}=\mathrm{NHAc}$

2d: $\mathrm{R}_{1}=\mathrm{R}_{4}=\mathrm{H} ; \mathrm{R}_{2}=\mathrm{OH} ; \mathrm{R}_{3}=\mathrm{NHAC}$

A number of 1,6-dideoxy-1,6-iminoheptitols 2, a novel family of polyhydroxylated azepanes that are higher homologues of deoxynojirimycin (1b), were prepared (Figure 1). ${ }^{6}$ Some of these derivatives show potent and specific glycosidase inhibition; e.g., compound $\mathbf{2 a}$ is a potent and selective inhibitor of coffee bean $\alpha$-galactosidase, compound $\mathbf{2 b}$ strongly inhibits bovine liver $\beta$-galactosidase and compounds $\mathbf{2 c}$ and $\mathbf{2 d}$ are inhibitors of $\beta$-acetyl- $N$-glucosaminidases. On the other hand, due to the unusual spatial distribution of the hydroxyl groups, ${ }^{7}$ these azepanes not only display a different inhibition profile compared to the previously reported polyhydroxylated azepanes, but they are also more prone to form hydrogen bonds with nitrogenated bases, thus improving their ability to bind to the minor groove of DNA. ${ }^{8}$

As a continuation of our interest in novel synthetic approaches to iminosugars, ${ }^{9}$ here we describe the synthesis of tetrahydroxyazepane 9 from shikimic acid (3).

\section{RESULTS AND DISCUSSION.}

In connection with our previous work in iminosugars, we present here our recent results concerning to the syntheses of the tetrahydroxyazepane 9 from shikimic acid (3).

Thus, as stated in the Scheme 1, protected 1-hydroxymethyl-3,4,5-cyclohexenetriol (5) was prepared from shikimic acid (3) via its methyl ester derivative 4. This key intemediate compound was transformed into the expected azepane 9 in three steps, including protection of its hydroxy groups, ozonolysis, reductive amination and final deprotection.

This novel synthetical approach to azepane 9 clearly improves a previous similar approach starting from quinic acid. ${ }^{10}$ 


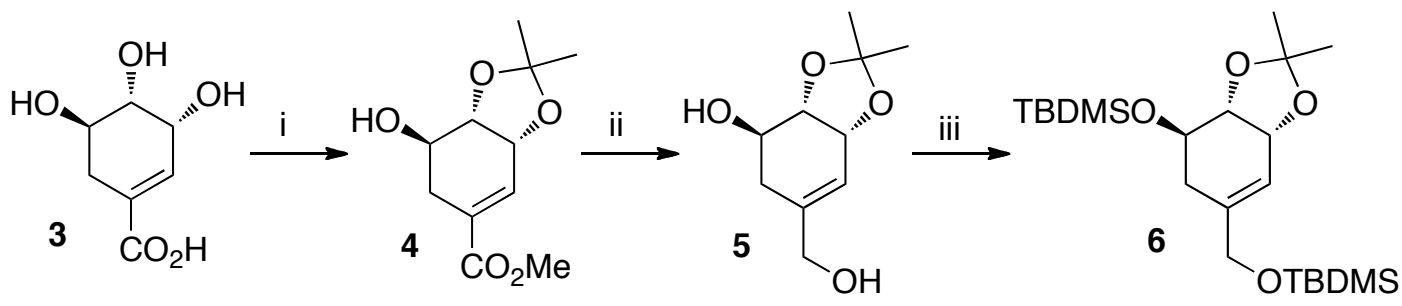

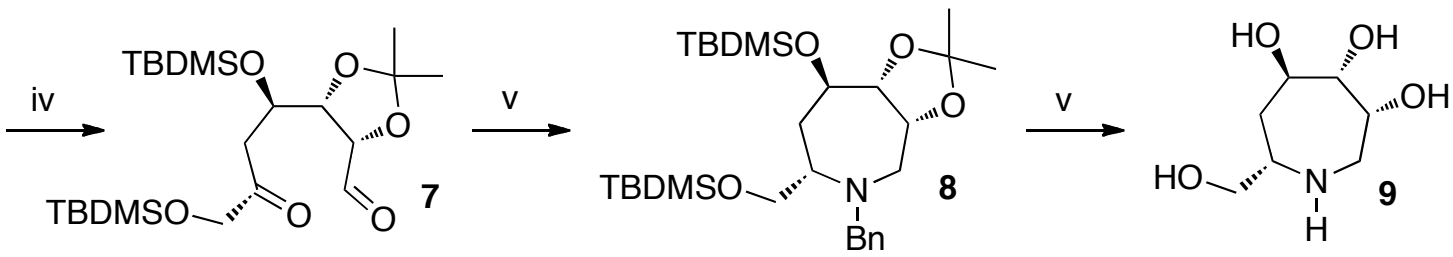

Scheme 1. Conditions.- (i) a) $\mathrm{MeOH}, \mathrm{H}_{2} \mathrm{SO}_{4}$; b) 2,2-dimethoxypropane, PTSA, acetone. (ii) DIBAL-H, THF. (iii) TBDMSCl, imidazole, DMF. iv) $\mathrm{O}_{3}, \mathrm{PPh}_{3}$; (v) $\mathrm{BnNH}_{2}, \mathrm{NaBH}(\mathrm{OAc})_{3}$. (vi) a) $\mathrm{H}_{2}, \mathrm{Pd} / \mathrm{C}$, b) $2 \mathrm{~N} \mathrm{HCl}, \mathrm{MeOH}$

\section{ACKNOWLEDGEMENTS.}

We thank the Spanish Ministry Science and Innovation and the Xunta de Galicia for financial support.

${ }^{1}$ a) Asano, N.; Nash, R. J.; Molyneux, R. J.; Fleet, G. W. J. Tetrahedron: Asymm. 2000, 11, 1645. b) Lillelund, V. H.; Jensen, H. H.; Liang, X.; Bols, M. Chem. Rev. 2002, 102, 515. c) Compain, P.; Martin, O. R. Iminosugars: from synthesis to therapeutic applications, John Wiley, Chichester, 2007.

2 a) Inoue, S.; Tsuruoka, T.; Niida, T. J. Antibiot. 1966, 19, 288. b) Asano, N.; Oseki, K.; Kiuz, H.; Matsui, K. J. Med. Chem. 1994, 37, 3701.

${ }^{3}$ Stütz, A. Iminosugars as glycosidase inhibitors: Nojirimycin and Beyond, Wiley-VCH, Weinheim, 1999.

${ }^{4}$ a) Paulsen, H.; Todt, K. Chem. Ber. 1967, 100, 512. b) Andreana, P. R.; Sanders, T.; Janczuk, A.; Warrick, J. I.; Wang, P. G. Tetrahedron Lett. 2002, 43, 6525. c) Joseph, C. C.; Regeling, H.; Zwanenburg, B.; Chittenden, G. J. F. Tetrahedron 2002, 58, 6907. d) Fuentes, J.; Gash, C.; Olano, D.; Pradera, M. A.; Repetto, P.; Sayago, F. J. Tetrahedron: Asymm. 2002, 13, 1743. e) Dhavale, D. D.; Chaudhari, V. D.; Tilekar, J. N. Tetrahedron 2003, 44, 7321; f) Li, H.; Liu, T.; Zhang, Y.; Fevre, S.; Bello, C.; Vogel, P.; Buttlers, T. D.; Oikonomakos, N. G; Marrot, J.; Blériot, Y. ChemBioChem 2008, 9,253 and references cited therein.

${ }^{5}$ Marcelo, F.; He, Y.; Yuzwa, S. A.; Nieto, L.; Jiménez-Barbero, J.; Sollogoub, M.; Vocadlo, D. J.; Davies, G. D.; Blériot, Y. J. Am. Chem. Soc. 2009, 131, 5390.

${ }^{6}$ a) Li, H.; Blériot, Y.; Chantereau, C.; Mallet, J. M.; Sollogoub, M.; Zhang, Y.; García, E. R.; Vogel, P.; Barbero, J. J.; Sinaÿ, P. Org. Biomol. Chem. 2004, 2, 1492; b) Li, H.; Marcelo, F.; Bello, C.; Vogel, P.; Buttlers, T. D.; Rauter, A. P.; Zhang, Y.; Sollogoub, M.; Blériot, Y. Bioorg. Med.. Chem. 2009, 17, 5598;

${ }^{7}$ Martínez-Mayorga, K.; Medina-Franco, J. L.; Mari, S.; Cañada, F. J.; Rodríguez-García, E.; Vogel, P.; Li, H.; Blériot, Y.; Sinaÿ, P.; Barbero, J. J. Eur. J. Org. Chem. 2004, 20, 4119.

${ }^{8}$ Johnson, H. A.; Thomas, N. R. Bioorg. Med. Chem. Lett. 2002, 12, 237.

9 a) José M. Otero, Raquel G. Soengas, Juan C. Estévez, Ramón J. Estévez, David J. Watkin, Emma L. Evinson, Robert J. Nash, and George W. J. Fleet Org. Lett. 2007, 9, 623. b) José M. Otero, Amalia M. Estévez, Raquel G. Soengas, Juan C. Estévez, Robert J. Nash, George W. J. Fleet, Ramón J. Estévez Tetrahedron: Asymm. 2008, 19, 2443. c) M. Begoña Pampín, Fernando Fernández, Juan C. Estévez, Ramón J. Estévez Tetrahedron: Asymm. 2009, 20, 503.

${ }^{10}$ Tzenge-Lien Shih, Ru-Ying Yang, Shiou-Ting Li, Cheng-Fan Chiang, and Chun-Hung Lin J. Org. Chem. 2007, 72, 4258 . 